\section{Taxing changes in prospect}

POLICY proposals published this week by Britain's Forestry Commission include for the first time special provisions for the protection of Britain's ancient seminatural woodland. In a consultative paper, Broadleaves in Britain, the commission suggests measures to minimize loss of all broadleaved woods and introduces guidelines agreed with the Nature Conservancy Council (NCC) for managing ancient seminatural woodland. This change of heart by the commission, which previously failed to recognize this category at all, is seen as a major concession to conservation interests.

According to a survey (as yet incomplete) by NCC, losses of ancient semi-natural woodland over the past 40-80 years in different counties range from 10 per cent to over 60 per cent, with most counties so far surveyed showing losses of over 40 per cent. The commission, which advises private foresters and manages its own forests, now recognizes a good case for slowing the rate of future loss, and proposes new management guidelines that will automatically check felling proposals and grant applications against the $\mathrm{NCC}$ register of ancient woodland. For woods so categorized there will be "a presumption in favour of maintaining the species already present" and owners will be persuaded to adopt methods of working that are "least disruptive of the woodland habitat". Broadleaved woodland in general should be maintained at about its present extent by requiring replanting with broadleaves after felling and allowing permanent clearing "only exceptionally",

The Forestry Commission has been under intense pressure from conservation groups to change its policies in this area, and has consulted extensively with interested parties for more than two years. There was therefore some surprise this week that the new document is consultative and not a definitive policy statement. Comments can be made on the proposals even at this stage. The commission hopes nevertheless to offer its final advice to government before the end of the year, as proposed tax changes and higher grants for establishing broadleaved woodlands will need ministerial approval.

Most of the broadleaved woodland in Britain is in private hands. Timber Growers UK Ltd, which represents foresters' interests, welcomes the Forestry Commission's proposals as a big step in the right direction. But, in the view of the association's chief executive, Mr Ronnie Williams, the commission could have been much firmer. Private foresters are keenly aware of the need to improve financial provisions for owners of broadleaved woodland, who are at a disadvantage compared with owners of the faster-growing and more profitable conifer stands. The Forestry Commission now proposes to

European biotechnology make it much easier for owners of mixed estates to claim tax relief on slow growing broadleaved plantations, a move welcomed by the timber growers. But, they say, the commission does not go far enough. Only by making broadleaved woodland management less of a financial burden in the hundred years or more from plantation to financial returns will the pressure to destroy ancient woodland be removed. It is also pointed out that the commission has hardly been providing a good example by its own planting policies: the vast majority of recent Forestry Commission plantations are of conifers.

The Forestry Commission makes much of the fact that the total area of broadleaves in Britain is now 15 per cent greater than in the $1940 \mathrm{~s}$, and its proposals could be briefly summed up by saying they aim to maintain the status quo. Private foresters, however, argue that a million acres of woodland were lost in two world wars and want a return to the levels of the turn of the century. But at present there are severe economic obstacles to broadleaved production, mainly the high costs of establishments, the low productivity and long rotations.

The Forestry Commission is currently reconsidering much of its research activity, and that on productivity of broadleaved species is one important area of discussion. The new Broadleaves in Britain document gives some indications of where it might be heading. The review group that produced the document considers it is "doubtful" whether improvements in growth rate can be achieved through the use of fertilizers, and in the long run the improvements will come about through genetics, most probably using vegetative propagation techniques and clonal testing. There is also, according to the group, a need for more information on total biomass production and how this is affected by spacing and harvesting regimes, as well as the properties of species mixtures and newly introduced species.

Tim Beardsley

\title{
Optimism abated as summit looms
}

Brussels

OFFICIALS of the European Commission fear that the Community's proposed biotechnology programme is falling foul of the present crisis in the Community's affairs. One sign of this is that the powerful agricultural lobby is mobilizing to block certain reforms that would have helped the growth of a strong biotechnology industry.

In spite of the generally favourable reception of the proposed programme by both research and industry ministers in November and December last year, that conjunction of omens seems now to be dissipating. "The alliance is coming unstuck", complained one official, citing the objections now raised by the sugar beet industry to a new pricing regime for the industrial use of sugar. "The sugar beet industry thinks that the biotechnology programme is the thin end of a wedge" leading to lower prices which, the official guesses, is the reason why agricultural ministers are now dragging their feet.

The Commission, meanwhile, is trimming its optimism about biotechnology to the changing wind. Last year, the Commission asked for a five-year programme costing 200 million European Currency Units (ECU) (about $£ 118$ million) but in its revised proposal put forward on 26 April, the Commission asked for only 88 million ECU covering only two of six of the original proposals - research and training and "concertation", with other biotechnology programmes.

At this level, the programme would represent a little more than a million dollars per country per year, an order of magnitude less than the Esprit information technology programme. The Netherlands and Denmark are unhappy about the size of even this proposal, while the United Kingdom and West Germany want the programme cut back drastically. "The council seems intent on reducing the whole thing to ashes before they have to build the whole edifice again", said one frustrated scientist.

The cuts and delays are especially galling for officials still smarting from the criticism earlier this year from the US Office of Technology Assessment that Europeans are not aggressive in commercializing biotechnology and pose little threat to the US industries.

At the twice postponed meeting of science ministers, now fixed for 29 June, there is even a danger that discussion of biotechnology will be swamped by two other items of high importance - telecommunications and the fusion programme. A spokesman for Research Commissioner Etienne Davignon insists that biotechnology retains its high priority, but British officials complain that they have yet to see where it fits into the Commission's larger scheme of things.

A further imponderable is that, by the end of June, the next Community summit at Fontainebleau may or may not have resolved the Community's budgetary crisis. The Commission may decide to go for a decision in principle on biotechnology, letting the question of funds hang loose until later, but in any case the programme will have to await an opinion of the newly elected European Parliament, and so is not likely to see the light of day before next year. "But if things go badly at Fontainebleau", said one senior European official, "it could be a catastrophe for European research",
David Price 